\title{
ANALISIS PERFORMANSI MODIFIKASI BINARY SPRAY AND WAIT MENGGUNAKAN PROPHET PADA DTN
}

\author{
Bima Adhiguna*, Tody Ariefianto Wibowo, Leanna Vidya Yovita \\ Program Studi Teknik Telekomunikasi, Fakultas Teknik Elektro, Universitas Telkom \\ *Corresponding author, e-mail: bima26.adhiguna@gmail.com ${ }^{1}$
}

\begin{abstract}
Abstrak-Delay Tolerant Network (DTN) memungkinkan komunikasi dalam lingkungan di mana mungkin tidak ada jalur end-to-end, peluang berkomunikasi datang dan pergi dan jarak antara pengirim dan penerima bisa sangat panjang dan bahkan tidak diketahui sebelumnya. Ada beberapa Routing Protocol pada DTN, diantaranya Binary Spray and Wait yang merupakan pengembangan dari Spray and Wait, dan PROPHET. Penelitian ini membahas tentang modifikasi Binary Spray and Wait pada tahap spray menggunakan teknik delivery predictability yang ada di PROPHET. Simulasi menggunakan ONE (Opportunistic Network Environtment) Simulator dan menganalisa Delivery Probability, Overhead Ratio, Buffer Time, Average Latency dan Average Remaining Energy pada pergerakan node Shortest Path Map Based dan Random Way Point. Berdasarkan pengamatan, dihasilkan Modifikasi Binary Spray and Wait meningkatkan performansi average latency dan buffer time dibanding dengan Binary Spray and Wait, namun menurunkan sedikit delivery probability dan memperbesar overhead ratio.
\end{abstract}

Kata Kunci : Delay Tolerant Network, Spray and Wait, PROPHET, Shortest Path Map Based, Random Way Point.

\begin{abstract}
Delay Tolerant Network (DTN) enabling communication in an environment where there may be no end-to-end link, opportunities to communicate come and go and the distance between sender and receiver can be very long and even previously unknown. There are some Routing Protocol on DTN, including Binary Spray and Wait is a development of Spray and Wait, and PROPHET. Research discuss about modification of Binary Spray and Wait in spray phase using delivery predictability in PROPHET. Simulation used ONE (Opportunistic Network Environtment) Simulator and analyze Delivery Probability, Overhead Ratio, Buffer Time, Average Latency and Average Remaining Energy in Shortest Path Map Based dan Random Way Point movement. Based on observation, the resulting modification of Binary Spray and Wait improve performance and buffer time average latency compared with Binary Spray and Wait, but slightly lower probability delivery and improving overhead ratio.
\end{abstract}

Keywords : Delay Tolerant Network, Spray and Wait, PROPHET, Shortest Path Map Based, Random Way Point.

Copyright (C) 2017 JNTE. All rights reserved

\section{PENDAHULUAN}

Fungsi utama pada jaringan komunikasi berkaitan dengan routing yang bertujuan untuk menemukan jalur dari sumber ke beberapa tujuan [2]. Ada dua tipe jaringan, yaitu Traditional Network dan Delay Tolerant Network. Dalam jaringan tradisional kita asumsikan bahwa ada jalur end-to-end antara node yang berkomunikasi. Akan tetapi, jalur yang dilalui tidak selamanya dapat diandalkan atau tersedia. Hal tersebut bisa menyebabkan paket yang dikirim tidak dapat diteruskan. Pada komunikasi Delay Tolerant Network memungkinkan paket tersebut bisa diteruskan sampai ke node tujuan.
Delay Tolerant Network (DTN) adalah paradigma jaringan komunikasi yang memungkinkan komunikasi dalam lingkungan di mana mungkin tidak ada jalur end-to-end, peluang komunikasi datang dan pergi dan intervalnya bisa sangat panjang dan bahkan tidak diketahui sebelumnya [4]. DTN menggunakan mekanisme Store and Forward untuk mengirim pesan dimana jika node sumber memiliki paket data yang akan dikirim tetapi jalur node berikutnya tidak tersedia, maka paket data tersebut akan disimpan sampai kontak berikutnya tersedia dan kemudian diteruskan. DTN memiliki beberapa protokol perutean, diantaranya adalah Spray and Wait dan PROPHET. 
Spray and Wait mempunyai dua tahap, tahap Spray dan tahap Wait [2]. Pada tahap Spray, node sumber meneruskan paket ke L node yang berbeda. Jika jalur ditemukan maka pesan atau transfer paket berhasil. Jika tidak maka tahap Wait dijalankan sampai menemukan node tujuan. Namun, pada Spray and Wait tidak diketahui bagaimana awalnya salinan pesan $\mathrm{L}$ disebar. Oleh sebab itu, muncul Binary Spray and Wait yang merupakan pengembangan dari Spray and Wait dimana ada inisialisasi jumlah salinan pesan di node sumber maupun node relay dahulu dan memberikan sebanyak L/2 salinan pesan untuk node yang ditemui. Pada PROPHET, paket diteruskan berdasarkan perhitungan probabilitas oleh setiap node ke node tujuan. Probabilitas ini disebut Delivery Predictability.

Berdasarkan ulasan di atas maka tercipta ide untuk memodifikasi Binary Spray and Wait yaitu pada tahap spray meneruskan salinan pesan ke node yang mempunyai nilai delivery

predictability lebih tinggi seperti pada PROPHET, dengan tujuan agar data yang diteruskan lebih cepat sampai node yang dituju.

\section{TINJAUAN PUSTAKA}

\subsection{Delay Tolerant Network (DTN)}

Delay Tolerant Network adalah paradigma jaringan komunikasi yang memungkinkan komunikasi dalam lingkungan di mana mungkin tidak ada jalur end-to-end, peluang komunikasi datang dan pergi dan intervalnya bisa sangat panjang dan bahkan tidak diketahui sebelumnya [4]. DTN menggunakan mekanisme Store and Forward untuk mengirim pesan dimana jika node sumber memiliki paket data yang akan dikirim tetapi jalur node berikutnya tidak tersedia, maka paket data tersebut akan disimpan sampai kontak berikutnya tersedia dan kemudian diteruskan.

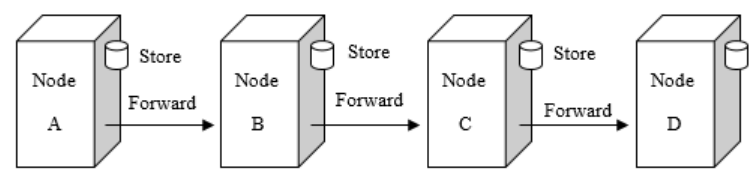

Gambar 1. Proses Store and Forward

Dalam DTN, proses Store and Forward dilakukan pada sebuah layer tambahan yang disebut Bundle Layer. Bundle layer adalah sebuah layer tambahan untuk memodifikasi paket data dengan fasilitas-fasilitas yang disediakan DTN. Bundle Layer memuat data dari sumber, informasi kontrol dan Bundle Header.

Bundle Layer terletak langsung di bawah application layer. Dalam bundle layer, data dari application layer akan dipecah-pecah menjadi bundle. Bundle inilah yang akan dikirim ke transport layer untuk diproses lebih lanjut.

Beberapa contoh jaringan berbasis DTN adalah ZebraNet untuk Wildlife tracking, Daknet yang memungkinkan penggunaan aplikasi internet di daerah pedesaan tanpa infrastruktur, OptraCom untuk monitoring populasi pada area yang luas, dll.

\subsection{Routing Protocol Pada DTN}

Routing Protocol (Protokol Perutean) merupakan sekumpulan aturan/ standar untuk menentukan bagaimana router dalam sebuah jaringan bisa berkomunikasi dan melakukan pertukaran informasi antara satu dan yang lainnya. Dalam teknologi Delay Tolerant Network, routing protocol dibagi menjadi 2 yaitu single copy routing protocol dan multicopy routing protocol. Single copy merupakan jenis routing protocol dimana hanya membentuk satu bundle untuk dikirim di dalam jaringan. Contoh routing protocol single copy yaitu first contact dan direct delivery. Skema berbeda ditunjukkan oleh multicopy, dimana protokol ini menggandakan bundle di dalam jaringan untuk memperbaiki probabilitas pengiriman dan mengurangi delay akibat pengiriman namun menambah bandwidth dan penyimpanan. Contoh routing protocol jenis multicopy yaitu Spray and Wait, Epidemic, MaxProp dan PROPHET.

\subsection{Spray and Wait}

Spray and Wait (SaW) memiliki 2 tahap, yaitu tahap spray dan tahap wait [4]. Node sumber awalnya menginisialisasi jumlah salinan pesan sejumlah L. Pada tahap spray, node sumber mengirimkan 1 salinan pesan ke L node yang berbeda. Jika node tujuan ditemukan maka pesan akan sukses dikirim. Apabila tidak, akan masuk tahap wait sampai direct transmission ke node tujuan.

\subsection{Binary Spray and Wait}

Binary Spray and Wait (BSW) merupakan peningkatan dari Spray and Wait. Pada BSW sumber pesan awalnya memiliki L salinan pesan. Ketika menemukan node pertama yang belum 
memiliki salinan, maka node sumber akan memberikan $\frac{L}{2}$ salinan kepada node tersebut dan $\frac{L}{2}$ tetap disimpan di node sumber. Proses diulang untuk node yang mempunyai L > 1, dan ketika tersisa hanya 1 salinan kemudian beralih ke tahap wait sampai transmisi langsung ke tujuan.

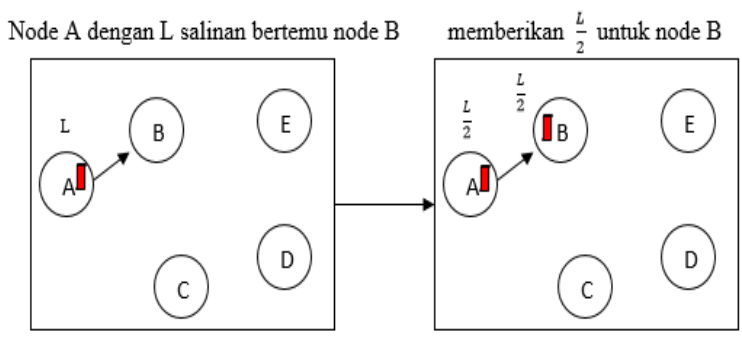

Gambar 2. Pengiriman Pesan $B S W$

\subsection{PROPHET}

Pada PROPHET pesan diteruskan berdasarkan perhitungan probabilitas/ peluang oleh setiap node ke setiap node tujuan [3]. Probabilitas ini disebut Delivery Predictability. Ketika dua node ditemukan, pesan akan diteruskan ke node yang mempunyai nilai delivery predictability tertinggi. Delivery Predictability ini menunjukan seberapa besar kemungkinan node akan mengirim pesan ke tujuan. Ketika dua node bertemu, mereka akan bertukar vektor ringkasan (summary vector) yang mana pada kasus ini juga terdiri dari informasi delivery predictability yang tersimpan pada node-node. Informasi ini digunakan untuk memperbarui vektor internal delivery predictability, dan informasi pada vektor ringkasan digunakan untuk menentukan pesan mana yang diminta dari node lain. Tahap perhitungan delivery predictability [3] :

- Update delivery matric saat node bertemu, hal ini diperlukan karena node-node yang sering bertemu mempunyai delivery predictability tinggi.

$P_{(a, b)}=P_{(a, b)}+\left(1-P_{(a, b) \text { old }}\right) \times P_{\text {init }}$

$P_{\text {init }} \in[0,1]:$ konstanta inisialisasi

- Pengiriman delivery predictability harus ada batas waktu.

$P_{(a, b)}=P_{(a, b) \text { old }} \times \gamma^{k}$

$\gamma^{k} \in[0,1]:$ konstanta batas waktu

- Delivery predictability juga mengikuti transitivitas, jika node A sering bertemu dengan node $\mathrm{B}$ dan node $\mathrm{B}$ sering bertemu dengan node $\mathrm{C}$ maka node $\mathrm{C}$ kemungkinan adalah node yang bagus untuk meneruskan pesan ke tujuan dari node $\mathrm{A}$.

$$
\begin{array}{r}
P_{(a, c)}=P_{(a, b)} \text { old }+\left(1-P_{(a, c) \text { old }}\right) \\
\times P_{(a, b)} \times P_{(b, c)} \times \beta
\end{array}
$$

$\beta$ : konstanta skala yang memutuskan seberapa besar pengaruh transitivitas yang harus dimiliki delivery predictability.

\subsection{Modifikasi Binary Spray and Wait menggunakan Delivery Predictability}

Modifikasi Binary Spray and Wait menggunakan Delivery Predictability terdapat dua tahap yaitu :

- Tahap Spray, pada tahap ini setiap node yang bertemu akan mengupdate delivery predictability seperti halnya di PROPHET, dan node akan memberikan $\frac{L}{2}$ salinan pesan kepada node yang mempunyai nilai delivery predictability lebih tinggi.

- Tahap Wait, pada tahap ini sama seperti BSW yaitu setelah masing-masing node hanya memiliki satu salinan pesan akan mengirim pesan secara direct transmission.

\section{METODOLOGI}

\subsection{Perancangan Sistem}

Simulasi ini membandingkan routing protocol pada DTN yaitu Binary Spray and Wait, PROPHET dan modifikasi Binary Spray and Wait, dengan ketentuan:

- Perancangan dan simulasi diterapkan pada Opportunistic Network Environtment (ONE) Simulator.

- Node menggambarkan pejalan kaki dan kendaraan.

- Mobilitas node menggunakan Shortest Path Map Based Movement dan Random Way Point. Untuk Shortest Path Map Based Movement menggunakan map Helsinki city Jepang.

- Pada saat konfigurasi node, yang diperhatikan yaitu jumlah node dan ukuran buffer masing-masing node.

Parameter keluaran yaitu : 1. delivery probability, merupakan perbandingan antara bundle yang dikirim dan dibentuk, 2. overhead ratio merupakan Perbandingan jumlah salinan pesan yang dibuat dengan pesan yang terkirim, 3. average latency, 
rata-rata waktu yang digunakan untuk mengirimkan pesan dari sumber ke tujuan, 4. buffer time yang mana merupakan lama waktu yang dibutuhkan pesan untuk antri di buffer node.

Tabel 1. Parameter Simulasi

\begin{tabular}{|c|l|l|}
\hline No & \multicolumn{2}{|c|}{ Parameter Uji Simulasi } \\
\hline 1. & Waktu Simulasi & $36000 \mathrm{~s}$ \\
\hline 2. & Jumlah Node & $10,50,100,200$ \\
\hline 3. & Interface & Wifi Interface \\
\hline 4. & Tipe Interface & Simple Broadcast \\
\hline 5. & Kecepatan Transmisi & $6 \mathrm{Mbps}$ \\
\hline 6. & Transmit Range & $100 \mathrm{~m}$ \\
\hline 7. & Mobilitas & $\begin{array}{l}\text { Shortest Path Map } \\
\text { Based Movement, } \\
\text { Random Way Point }\end{array}$ \\
\hline 8. & Ukuran Buffer & $5 \mathrm{M}, 10 \mathrm{M}, 15 \mathrm{M}$ \\
\hline 9. & Kecepatan Node & 25 to 27m/sec \\
\hline 10. & Ukuran Pesan & $512 \mathrm{~Kb}$ \\
\hline 11. & Message Interval & 25 to 35 sec \\
\hline 12. & Message TTL & $300 \mathrm{minutes}$ \\
\hline
\end{tabular}

\subsection{Alur Simulasi}

Pada simulasi penelitian ini dilakukan modifikasi routing protocol Spray and Wait pada bagian fase Spray. Kemudian script yang telah berhasil dimodifikasi tersebut disimulasikan dan dianalisis hasilnya berdasarkan parameter keluaran seperti delivery probability, overhead ratio, average latency, dan buffer time.

\subsection{Pengaruh Jumlah Node}

Tabel 2. Skenario 1 Pengaruh Jumlah Node

\begin{tabular}{|c|c|c|}
\hline Skenario & Mobilitas & $\begin{array}{c}\text { Jumlah } \\
\text { Node }\end{array}$ \\
\hline \multirow{4}{*}{ Skenario 1} & \multirow{4}{*}{$\begin{array}{c}\text { Random Way Point, } \\
\text { Map Based } \\
\text { Movement }\end{array}$} & 10 \\
\hline & & 50 \\
\hline & & 100 \\
\hline & & 200 \\
\hline
\end{tabular}

Skenario perubahan jumlah node dilakukan untuk melihat performansi dari masing-masing routing protocol yang di analisis yaitu Binary Spray and Wait, PROPHET dan modifikasi Binary Spray and Wait, terhadap perubahan mobilitas node.

\subsection{Pengaruh Ukuran Buffer}

Skenario perubahan ukuran buffer dilakukan untuk melihat performansi dari masing-masing routing protocol yang di analisis yaitu Binary Spray and Wait, PROPHET dan modifikasi Binary Spray and Wait, terhadap perubahan mobilitas node.

Tabel 3. Skenario 2 Pengaruh Ukuran Buffer

\begin{tabular}{|c|c|c|}
\hline Skenario & Mobilitas & $\begin{array}{c}\text { Ukuran } \\
\text { Buffer }\end{array}$ \\
\hline \multirow{3}{*}{ Skenario 2 } & $\begin{array}{c}\text { Random Way Point, } \\
\text { Map Based } \\
\text { Movement }\end{array}$ & $5 \mathrm{MB}$ \\
\cline { 3 - 3 } & & $10 \mathrm{MB}$ \\
\cline { 3 - 3 } & & $15 \mathrm{MB}$ \\
\hline
\end{tabular}

\section{HASIL DAN PEMBAHASAN}

Simulasi menggunakan ONE Simulator dengan keluaran data .txt kemudian diolah ke dalam bentuk grafik untuk dianalisis.

\subsection{Analisis Performansi Protokol Routing Terhadap Perubahan Jumlah Node. \\ 4.1.1. Random Way Point}

1. Delivery Probability

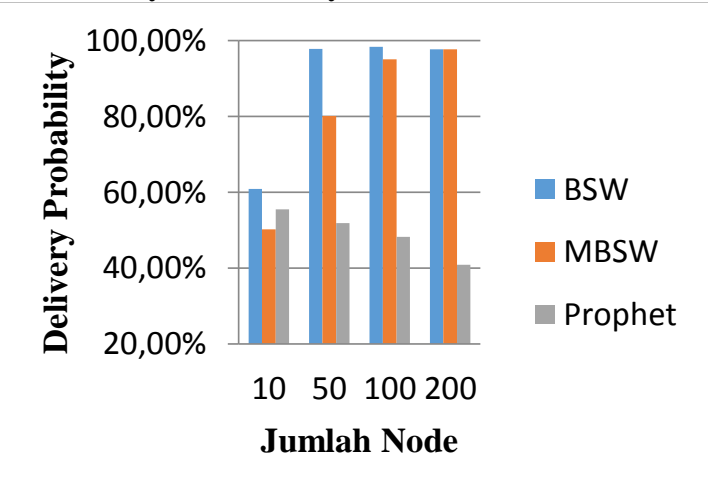

Gambar 3. Pengaruh Perubahan Jumlah Node Terhadap Delivery Probability

Untuk Binary Spray and Wait dan modifikasi tahap spray pada Modifikasi Binary Spray and Wait, nilai delivery probability semakin meningkat seiring dengan meningkatnya jumlah node. Hal tersebut karena semakin banyak jumlah node maka akan semakin banyak intensitas pertemuan node, namun pada modifikasi tahap spray pada $M B S W$ nilai delivery probability tidak sebesar pada Binary Spray and Wait karena beban pada buffer yang lebih tinggi menyebabkan pesan yang diteruskan lebih sedikit. Sedangkan pada PROPHET, semakin meningkat jumlah node nilai delivery probability 
semakin menurun, karena selain beban pada buffer yang lebih tinggi, juga tidak ada batasan jumlah salinan pesan, yang akan menambah beban pada buffer. Semakin banyak beban pada buffer semakin banyak juga pesan yang didrop, karena ukuran buffer terbatas.

Modifikasi Binary Spray and Wait menurunkan nilai delivery probability pada Binary Spray and Wait yaitu pada 10 node sebesar $17.51 \%$, 50 node sebesar $18.12 \%, 100$ node sebesar $3.34 \%$ dan pada node 200 sebesar $0 \%$.

2. Overhead Ratio

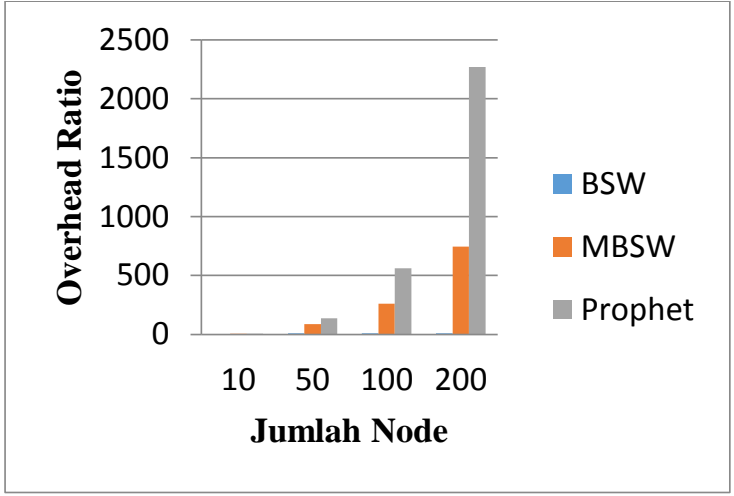

Gambar 4. Pengaruh Perubahan Jumlah Node Terhadap Overhead Ratio

Dari data Gambar 4 di atas dapat dilihat bahwa bahwa semakin bertambah jumlah node maka akan semakin tinggi nilai overhead ratio, karena akan semakin banyak jumlah pesan yang dikirim. Pada Binary Spray and Wait memiliki nilai overhead ratio paling kecil dibanding kedua routing protocol yang lain, karena salinan pesan yang dikirim terbatas dan hanya mengirimkan salinan pesan saja sehingga perbandingan jumlah pesan yang diteruskan dengan jumlah pesan yang terkirim semakin kecil. Berbeda dengan modifikasi tahap spray pada Modifikasi Binary Spray and Wait dimana selain mengirimkan salinan pesan yang sudah ditentukan, juga saling bertukar informasi delivery predictability yang menyebabkan perbandingan jumlah pesan yang diteruskan dengan pesan yang terkirim semakin lebih tinggi dibanding Binary Spray and Wait. Sedangkan pada PROPHET memiliki nilai overhead ratio paling tinggi dari kedua routing protocol yang lain, karena selain selama simulasi berlangsung saling bertukar informasi delivery predictability, PROPHET juga mengirimkan pesan yang jumlahnya tidak ditentukan dan akan terus mengirim pesan ke node yang mempunyai nilai delivery predictability lebih tinggi sampai ke tujuan yang menyebabkan perbandingan jumlah pesan yang diteruskan dengan jumlah pesan yang terkirim besar.

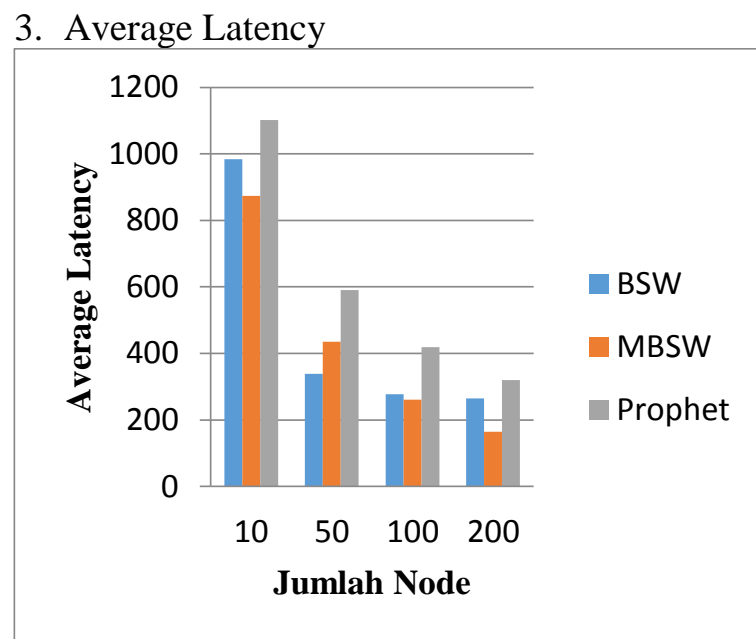

Gambar 5. Pengaruh Perubahan Jumlah Node Terhadap Average Latency

Dari data dapat dilihat bahwa semakin bertambah jumlah node semakin menurun nilai average latency masing-masing routing protocol. Pada PROPHET memiliki nilai average latency paling tinggi, karena mengirimkan pesan ke node yang mempunyai nilai delivery predictability lebih tinggi, dan hal tersebut membutuhkan waktu untuk menemukan node yang mempunyai delivery predictability lebih tinggi. $B S W$ melakukan direct transmission pada tahap wait yang mana juga membutuhkan waktu sampai bertemu node yang dituju. Modifikasi tahap spray pada $M B S W$ membuat nilai average latency kecil, karena pada tahap spray salinan pesan dikirimkan ke node yang mempunyai nilai delivery predictability paling tinggi sehingga tidak memerlukan waktu yang lama untuk direct transmission di tahap wait.

Modifikasi Binary Spray and Wait menyebabkan nilai average latency semakin cepat dibandingkan dengan Binary Spray and Wait, untuk 10 node lebih cepat sebesar 11.19\%, namun pada node $50 \mathrm{MBSW}$ lebih lama sebesar $28.69 \%$, untuk 100 node lebih cepat sebesar $5.57 \%$, dan untuk 200 node lebih cepat sebesar $37.91 \%$. 
4. Buffer Time

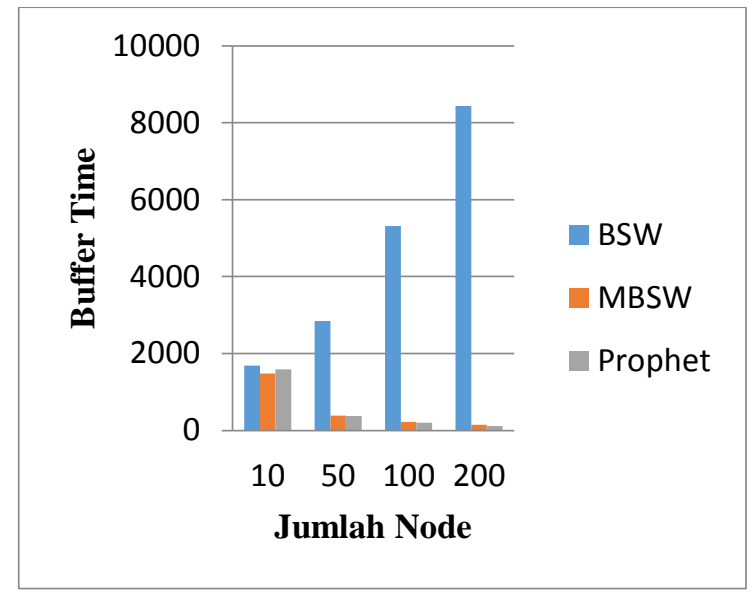

Gambar 6. Pengaruh Perubahan Jumlah Node Terhadap Buffer Time

Data menunjukkan bahwa untuk modifikasi tahap spray pada $M B S W$ dan PROPHET cenderung menurun seiring pertambahan jumlah node. Hal tersebut karena pada kedua routing protocol tersebut mengirim pesan ke node yang mempunyai delivery predictability lebih tinggi. Berbeda dengan Binary Spray and Wait yang mana pada tahap spray mengirimkan salinan pesan ke setiap node yang ditemuinya yang menyebabkan pada tahap wait akan lama berada di buffer sampai direct transmission.

Modifikasi Binary Spray and Wait menyebabkan nilai Buffer Time semakin kecil dibandingkan dengan Binary Spray and Wait, untuk 10 node lebih kecil sebesar $11.96 \%$, untuk 50 node lebih kecil sebesar $86.37 \%$, untuk 100 node lebih kecil sebesar $95.88 \%$ dan untuk 200 node lebih kecil sebesar 98.24\%.

\subsubsection{Map Based Movement}

Dari data Gambar 7 dapat dilihat bahwa Binary Spray and Wait dan modifikasi tahap spray pada Modifikasi Binary Spray and Wait, nilai delivery probability semakin meningkat seiring dengan meningkatnya jumlah node. Hal tersebut karena semakin banyak jumlah node maka akan semakin banyak contact antar node, namun pada modifikasi tahap spray pada $M B S W$ nilai delivery probability tidak sebesar pada Binary Spray and Wait karena. Sedangkan pada PROPHET, semakin meningkat jumlah node nilai delivery probability semakin menurun, karena selain beban pada buffer yang lebih tinggi, juga tidak ada batasan jumlah salinan pesan, yang akan menambah beban pada buffer. Semakin banyak beban pada buffer semakin banyak juga pesan yang didrop, karena ukuran buffer terbatas.

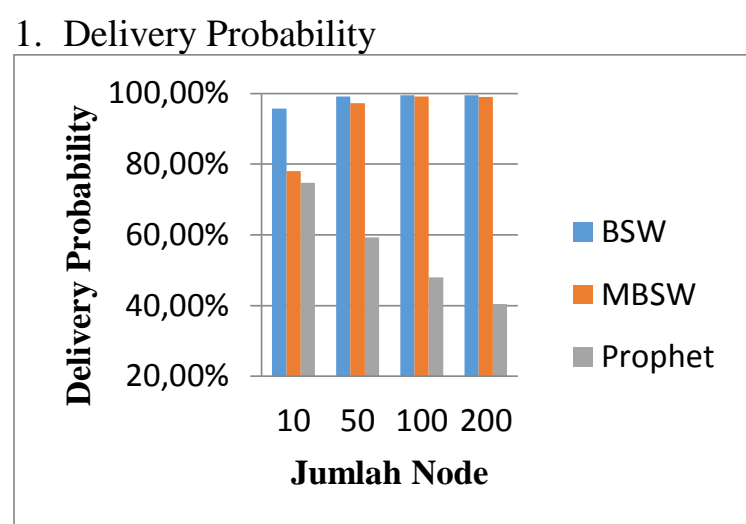

Gambar 7. Pengaruh Perubahan Jumlah Node Terhadap Delivery Probability

Modifikasi Binary Spray and Wait menurunkan nilai delivery probability pada Binary Spray and Wait yaitu untuk 10 node sebesar $18.52 \%$, 50 node sebesar $1.98 \%, 100$ node sebesar $0.33 \%$ dan 200 node sebesar $0.5 \%$.

2. Overhead Ratio

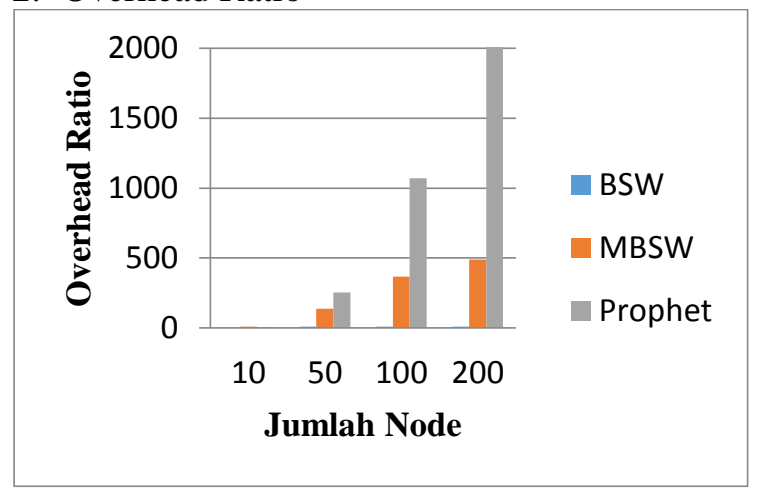

Gambar 8. Pengaruh Perubahan Jumlah Node Terhadap Overhead Ratio

Dari data Gambar 8 di atas dapat dilihat bahwa semakin bertambah jumlah node maka akan semakin tinggi nilai overhead ratio, karena akan semakin banyak jumlah pesan yang dikirim. Pada Binary Spray and Wait memiliki nilai overhead ratio paling kecil dibanding kedua routing protocol yang lain, karena salinan pesan yang dikirim terbatas dan hanya mengirimkan salinan pesan saja sehingga perbandingan jumlah pesan yang diteruskan dengan jumlah pesan yang 
terkirim semakin kecil. Berbeda dengan modifikasi tahap spray pada Modifikasi Binary Spray and Wait dimana selain mengirimkan salinan pesan yang sudah ditentukan, juga saling bertukar informasi delivery predictability yang menyebabkan perbandingan jumlah pesan yang diteruskan dengan pesan yang terkirim semakin lebih tinggi dibanding Binary Spray and Wait. Sedangkan pada PROPHET memiliki nilai overhead ratio paling tinggi dari kedua routing protocol yang lain, karena selain selama simulasi berlangsung saling bertukar informasi delivery predictability, PROPHET juga mengirimkan pesan yang jumlahnya tidak ditentukan dan akan terus mengirim pesan ke node yang mempunyai nilai delivery predictability lebih tinggi sampai ke tujuan yang menyebabkan perbandingan jumlah pesan yang diteruskan dengan jumlah pesan yang terkirim besar.

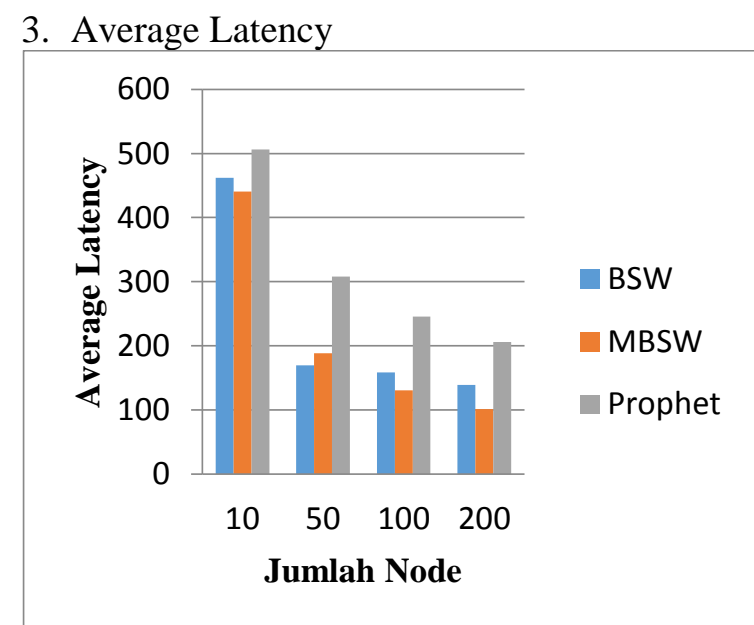

Gambar 9. Pengaruh Perubahan Jumlah Node Terhadap Average Latency

Data menunjukan semakin bertambah jumlah node, semakin menurun nilai average latency masing-masing routing protocol, karena akan semakin banyak intensitas pertemuan antar node. Pada PROPHET memiliki nilai average latency paling tinggi, karena mengirimkan pesan ke node yang mempunyai nilai delivery predictability lebih tinggi, dan hal tersebut membutuhkan waktu untuk menemukannya. $B S W$ melakukan direct transmission pada tahap wait yang mana juga membutuhkan waktu sampai ketemu node tujuan. Modifikasi tahap spray pada $M B S W$ membuat nilai average latency lebih kecil dari $B S W$, karena pada tahap spray salinan pesan dikirimkan ke node yang mempunyai nilai delivery predictability lebih tinggi sehingga tidak memerlukan waktu yang lama untuk direct transmission di tahap wait.

Modifikasi Binary Spray and Wait menyebabkan nilai average latency semakin cepat dibandingkan dengan Binary Spray and Wait, untuk 10 node lebih cepat sebesar $4.68 \%$, namun pada node $50 \mathrm{MBSW}$ lebih lama sebesar $11.05 \%$, untuk 100 node lebih cepat sebesar $17.88 \%$, dan untuk 200 node lebih cepat sebesar $27.31 \%$.

4. Buffer Time

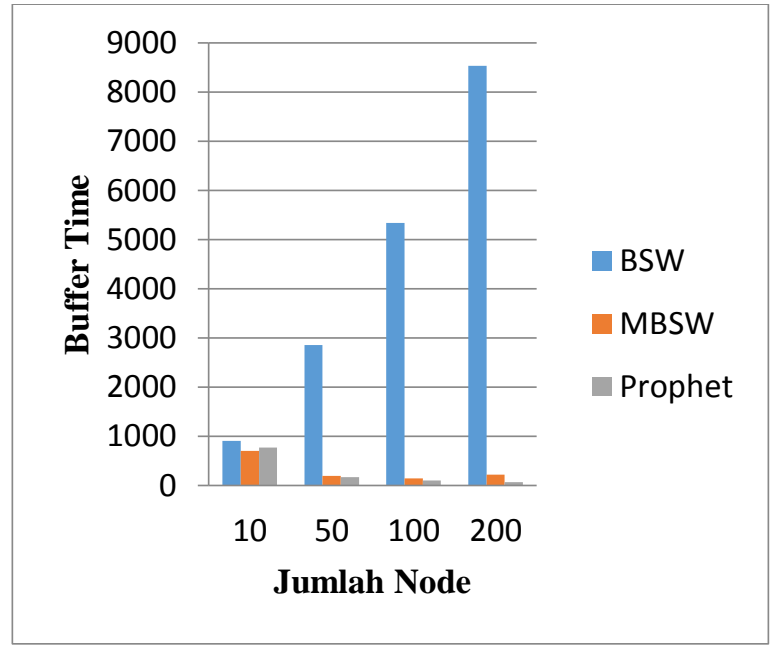

Gambar 10. Pengaruh Perubahan Jumlah Node Terhadap Buffer Time

Data menunjukkan bahwa untuk modifikasi tahap spray pada $M B S W$ dan PROPHET nilai Buffer Time cenderung menurun seiring pertambahan jumlah node. Hal tersebut karena pada kedua routing protocol tersebut mengirim pesan ke node yang mempunyai delivery predictability lebih tinggi. Berbeda dengan Binary Spray and Wait yang mana pada tahap spray mengirimkan salinan pesan ke setiap node yang ditemuinya yang menyebabkan pada tahap wait akan lama berada di buffer sampai direct transmission.

Modifikasi Binary Spray and Wait menyebabkan nilai Buffer Time semakin kecil dibandingkan dengan Binary Spray and Wait, untuk 10 node lebih kecil sebesar $22.15 \%$, untuk 50 node lebih kecil sebesar $92.94 \%$, untuk 100 node lebih kecil sebesar $97.19 \%$ dan untuk 200 node lebih kecil sebesar $97.37 \%$. 


\subsection{Analisis Performansi Protokol Routing Terhadap Perubahan Ukuran Buffer. \\ 4.2.1. Random Way Point}

1. Delivery Probability

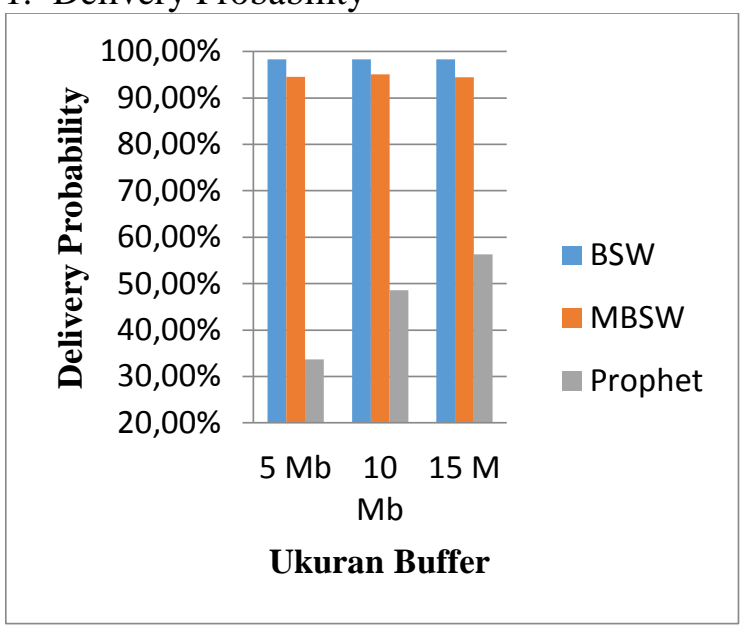

Gambar 11. Pengaruh Perubahan Ukuran Buffer Terhadap Delivery Probability

Dari data Gambar 11 dapat dilihat bahwa pada Binary Spray and Wait nilai delivery probability konstan, karena jumlah salinan pesan yang dikirim dan yang ditampung di buffer sama untuk setiap penambahan ukuran buffer. Modifikasi tahap spray pada $M B S W$ memiliki nilai delivery probability yang meningkat seiring dengan penambahan ukuran buffer, karena walaupun jumlah salinan pesan sama, namun pada MBSW juga saling bertukar infomasi delivery predictability yang mana membutuhkan ruang. Pada PROPHET nilai delivery probability meningkat seiring pertambahan ukuran buffer, sama halnya dengan MBSW melakukan pertukaran informasi delivery predictability, namun bedanya pada PROPHET jumlah salinan pesan yang dikirimkan tidak ada batasannya sehingga akan terus mengirim pesan ke node yang mempunyai nilai delivery predictability lebih tinggi sampai ke tujuan yang menyebabkan beban semakin banyak dan pesan yang didrop semakin banyak juga, sehingga nilai delivery probability nya lebih kecil dibandingkan dengan kedua routing protocol lainnya.

Modifikasi Binary Spray and Wait menurunkan nilai delivery probability pada Binary Spray and Wait yaitu untuk ukuran buffer $5 \mathrm{Mb}$ sebesar $3.84 \%$, ukuran buffer $10 \mathrm{Mb}$ sebesar 3.34\% dan untuk ukuran buffer $15 \mathrm{Mb}$ sebesar $4.01 \%$.
2. Overhead Ratio

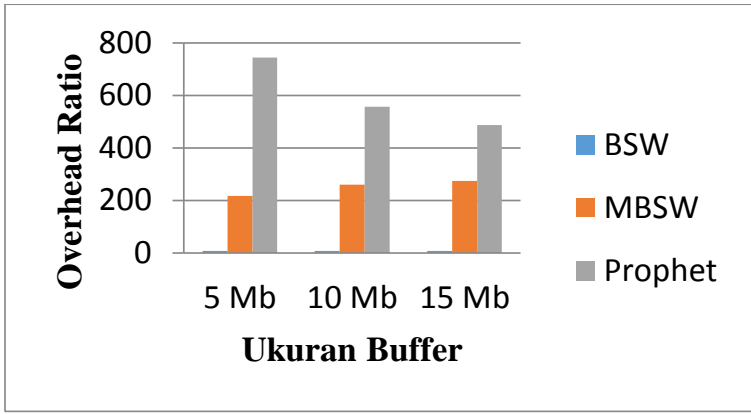

Gambar 12. Pengaruh Perubahan Ukuran Buffer Terhadap Overhead ratio

Hasil menunjukan overhead ratio pada PROPHET paling tinggi dari kedua routing protocol lainnya, karena pada PROPHET perbandingan jumlah pesan yang diteruskan dengan pesan yang terkirim paling besar diantara keduanya.

\section{Average Latency}

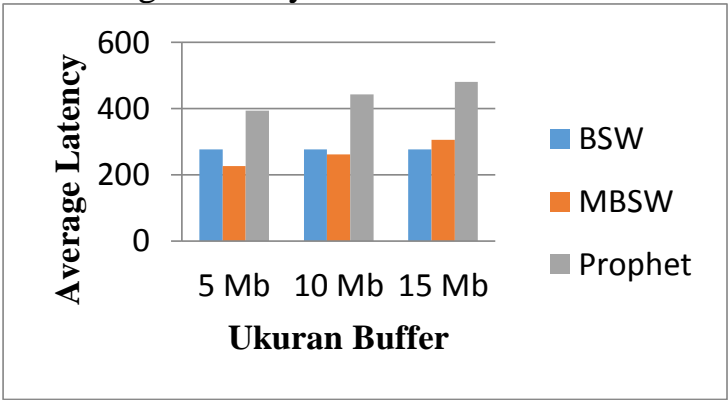

Gambar 13. Pengaruh Perubahan Ukuran Buffer Terhadap Average Latency

Hasil menunjukan routing protocol modifikasi tahap spray pada $M B S W$ mempunyai nilai average latency paling kecil karena pada tahap spray mengirimkan pesan ke node yang mempunyai nilai delivery predictability lebih tinggi sehingga direct transmission pada fase wait akan semakin cepat. $B S W$ memili nilai average latency paling tinggi karena $B S W$ mengirimkan salinan pesan ke setiap node yang ditemuinya tanpa melihat probabilitas pertemuan node sehingga lama sampai ke tujuan.

Modifikasi Binary Spray and Wait menyebabkan nilai average latency semakin cepat dibandingkan dengan Binary Spray and Wait, pada ukuran buffer $5 \mathrm{Mb}$ lebih cepat sebesar $18.13 \%$, ukuran buffer $10 \mathrm{Mb}$ lebih cepat $5.57 \%$, namun pada ukuran $15 \mathrm{Mb}$ lebih lambat sebesar $10.32 \%$. 
4. Buffer Time

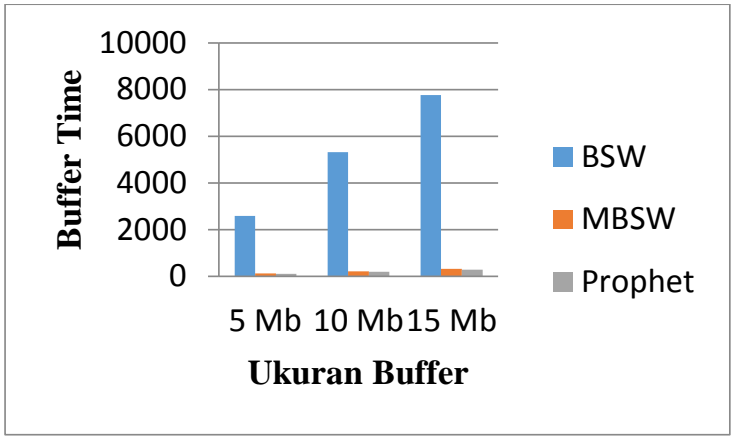

Gambar 14. Pengaruh Perubahan Ukuran Buffer Terhadap Buffer Time

Hasil menunjukan bahwa PROPHET mempunyai nilai buffer time paling kecil, karena routing protocol tersebut mengirimkan pesan ke node yang mempunyai nilai delivery predictability tinggi sehingga pesan tidak lama berada di buffer. Routing protocol modifikasi tahap spray pada Binary Spray and Wait mempunyai nilai buffer time kecil namun masih di atas PROPHET, sama halnya dengan PROPHET modifikasi pada tahap spray pada $M B S W$ meneruskan salinan pesan ke node yang mempunyai nilai delivery predictability lebih tinggi. Binary Spray and Wait mempunyai nilai buffer time paling tinggi dari kedua routing protocol yang lain, karena pada $B S W$ meneruskan salinan pesan ke setiap node yang ditemuinya tanpa melihat probabilitas pertemunnya, sehingga akan membuat pesan lama berada di buffer.

Modifikasi Binary Spray and Wait menyebabkan nilai Buffer Time semakin kecil dibandingkan dengan Binary Spray and Wait, pada ukuran buffer $5 \mathrm{Mb}$ lebih kecil 95.16\%, pada ukuran buffer $10 \mathrm{Mb}$ lebih kecil sebesar 95.88\% dan pada ukuran buffer $15 \mathrm{Mb}$ lebih kecil sebesar $95.91 \%$.

\subsubsection{Map Based Movement}

Dari data Gambar 15 dapat dilihat bahwa pada Binary Spray and Wait nilai delivery probability konstan, karena jumlah salinan pesan yang dikirim dan yang ditampung di buffer sama untuk setiap penambahan ukuran buffer. Modifikasi tahap spray pada $M B S W$ memiliki nilai delivery probability yang meningkat seiring dengan penambahan ukuran buffer, karena walaupun jumlah salinan pesan sama, namun pada MBSW juga saling bertukar infomasi delivery predictability yang mana membutuhkan ruang. Pada PROPHET nilai delivery probability meningkat seiring pertambahan ukuran buffer, sama halnya dengan MBSW melakukan pertukaran informasi delivery predictability, namun bedanya pada PROPHET jumlah salinan pesan yang dikirimkan tidak ada batasannya sehingga akan terus mengirim pesan ke node yang mempunyai nilai delivery predictability lebih tinggi sampai ke tujuan yang menyebabkan beban semakin banyak dan pesan yang didrop semakin banyak juga, sehingga nilai delivery probability nya lebih kecil dibandingkan dengan kedua routing protocol lainnya.

1. Delivery Probability

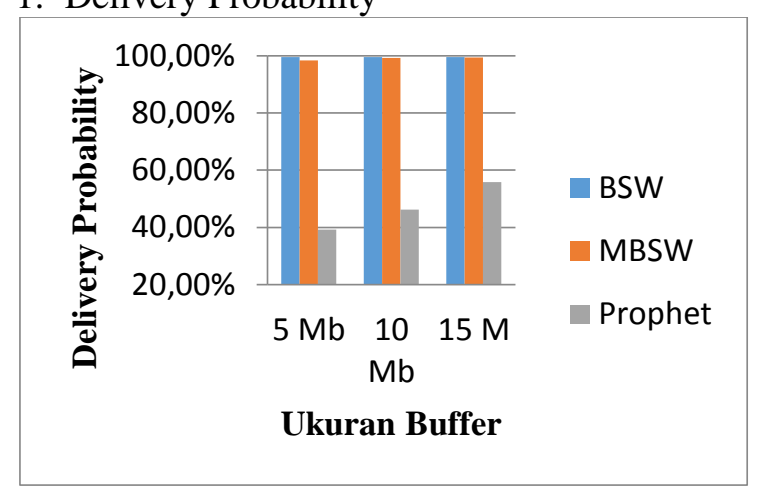

Gambar 15. Pengaruh Perubahan Ukuran Buffer Terhadap Delivery Probability

Modifikasi Binary Spray and Wait menurunkan nilai delivery probability pada Binary Spray and Wait yaitu untuk ukuran buffer $5 \mathrm{Mb}$ sebesar $1.16 \%$, ukuran buffer $10 \mathrm{Mb}$ sebesar $0.33 \%$ dan untuk ukuran buffer $15 \mathrm{Mb}$ sebesar $0.17 \%$.

2. Overhead Ratio

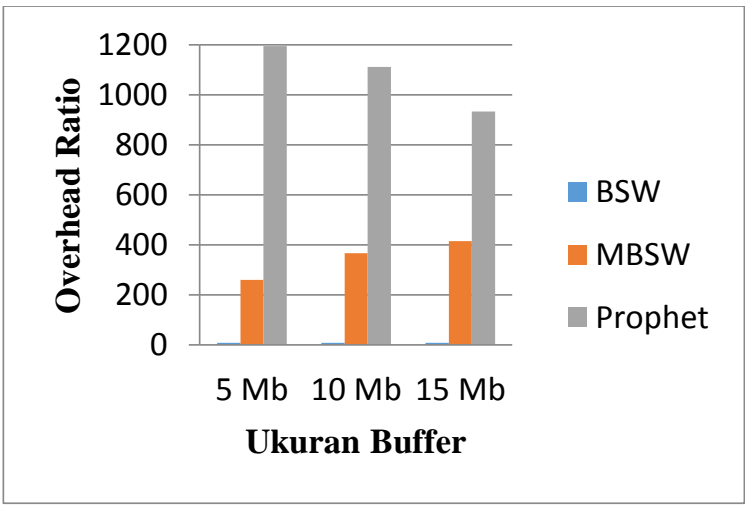

Gambar 16. Pengaruh Perubahan Ukuran Buffer Terhadap Overhead ratio 
Hasil menunjukan overhead ratio pada PROPHET paling tinggi dari kedua routing protocol lainnya, karena pada PROPHET perbandingan jumlah pesan yang diteruskan dengan pesan yang terkirim paling besar diantara keduanya.

\section{Average Latency}

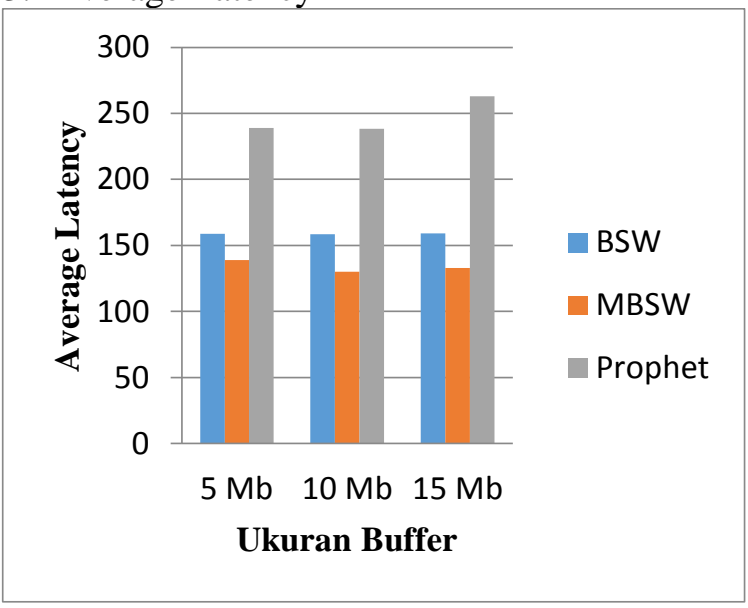

Gambar 17. Pengaruh Perubahan Ukuran Buffer Terhadap Average Latency

Hasil menunjukan PROPHET mempunyai nilai average latency paling besar dibanding kedua routing protocol yang lain, karena pada PROPHET mengirimkan pesan ke node yang mempunyai nilai delivery predictability lebih tinggi sampai ke tujuan, yang mana membutuhkan waktu yang lama. $B S W$ memiliki nilai average latency di bawah $P R O P H E T$ karena $B S W$ pada tahap spray mengirimkan salinan pesan ke setiap node yang ditemuinya tanpa melihat probabilitas pertemuan node sehingga pada tahap wait akan membutuhkan waktu yang lama sampai direct transmission. Modifikasi tahap spray pada $M B S W$ mempunyai nilai average latency paling kecil karena pada tahap spray mengirimkan pesan ke node yang mempunyai nilai delivery predictability lebih tinggi sehingga direct transmission pada tahap wait akan semakin cepat.

Modifikasi Binary Spray and Wait menyebabkan nilai average latency semakin cepat dibandingkan dengan Binary Spray and Wait, pada ukuran buffer $5 \mathrm{Mb}$ lebih cepat sebesar $12.53 \%$, ukuran buffer $10 \mathrm{Mb}$ lebih cepat $17.88 \%$, dan pada ukuran $15 \mathrm{Mb}$ lebih cepat sebesar $16.43 \%$.
4. Buffer Time

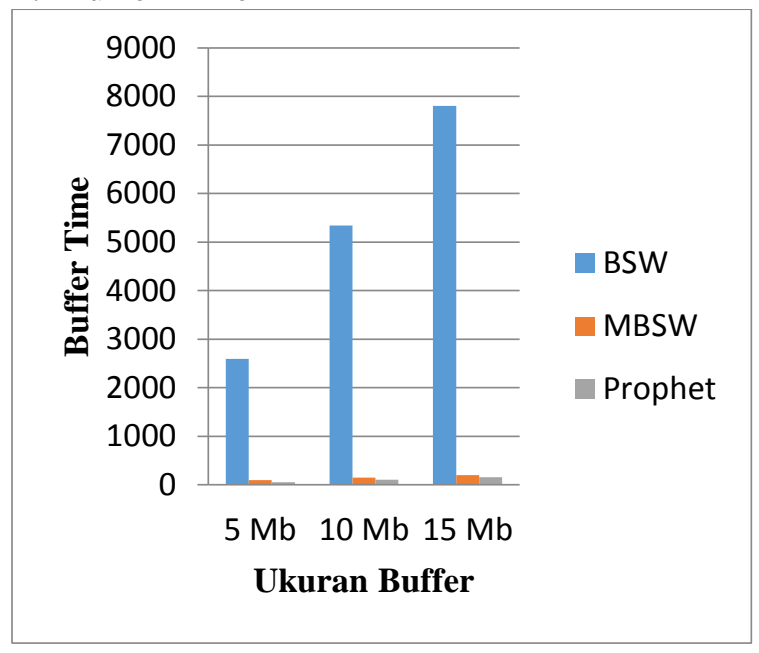

Gambar 18. Pengaruh Perubahan Ukuran Buffer Terhadap Buffer Time

Hasil menunjukan bahwa semakin besar ukuran buffer akan menyebabkan nilai buffer time untuk masing-masing routing protocol meningkat, karena jumlah pesan yang ditampung di buffer akan semakin banyak. PROPHET mempunyai nilai buffer time paling kecil, karena routing protocol tersebut mengirimkan pesan ke node yang mempunyai nilai delivery predictability tinggi sehingga pesan tidak lama berada di buffer. Routing protocol modifikasi tahap spray pada MBSW mempunyai nilai buffer time kecil namun masih di atas PROPHET, sama halnya dengan PROPHET modifikasi pada tahap spray meneruskan salinan pesan ke node yang mempunyai nilai delivery predictability lebih tinggi akan tetapi pada tahap wait membutuhkan waktu sedikit lebih lama sampai direct transmission. Binary Spray and Wait mempunyai nilai buffer time paling tinggi dari kedua routing protocol yang lain, karena pada tahap spray meneruskan salinan pesan ke setiap node yang ditemuinya tanpa melihat probabilitas pertemunnya, sehingga akan membuat pesan lama berada di buffer.

Modifikasi Binary Spray and Wait menyebabkan nilai Buffer Time semakin kecil dibandingkan dengan Binary Spray and Wait, pada ukuran buffer $5 \mathrm{Mb}$ lebih kecil $96.12 \%$, pada ukuran buffer $10 \mathrm{Mb}$ lebih kecil sebesar 97.19\% dan pada ukuran buffer $15 \mathrm{Mb}$ lebih kecil sebesar $97.43 \%$. 


\section{KESIMPULAN}

Kesimpulan yang dapat diambil dari seluruh proses perancangan, simulasi dan analisis adalah sebagai berikut:

- Performansi modifikasi tahap spray pada Modifikasi Binary Spray and Wait menggunakan delivery predictability lebih unggul pada sisi average latency dan buffer time dibanding Binary Spray and Wait. Namun untuk delivery probability sedikit di bawah $B S W$ dan overhead ratio jauh lebih tinggi dari $B S W$. Sedangkan jika modifikasi tahap spray pada $M B S W$ dibandingkan dengan PROPHET, performansi delivery probability, overhead ratio, dan average latency lebih unggul namun buffer time lebih bagus PROPHET.

- Performansi MBSW, Binary Spray and Wait, dan PROPHET bagus pada model pergerakan node Shortest Path Map Based Movement dibandingkan pada Random Way Point.

\section{DAFTAR PUSTAKA}

[1] Anjula Mehto and Meenu Chawla, Ph.D, "Modified Different Neighbor History Spray and Wait using PROPHET in Delay Tolerant Network", International Journal of Computer Applications (0975 - 8887), January 2014.

[2] Bijal Patel, Krupa Dave and Vyomal Pandya, "Spray and Wait Routing Protocol in Delay Tolerant Networks", International Journal of Emerging Technology and Advanced Engineering, May 2014.

[3] A. Lindgren, A. Doria, and O. Schelen, "Probabilistic routing in intermittently connected networks. SIGMOBILE Mob," Comput. Commun. Rev. vol. 7, no. 3, 2003

[4] Keranen,Ari. "Opportinistic Network Environtment Simulator", Helsinky University of Technology, May 2008.
[5] Bhed Bahadur Bista and Dand B. Rawat.

" Energy Consumption and Performance of Delay Tolerant Network Routing Protocols under Different Mobility Models", 7th International Conference on Intelligent Systems, Modelling and Simulation, 2016.

[6] Carlo Caini, Haitham Cruickshank, Stephen Farrell and Mario Marchese, "Delay- and Disruption-Tolerant Networking (DTN): An Alternative Solution for Future Satellite Networking Applications", 2011.

[7] Thrasyvoulos Spyropoulos, Konstantinos Psounis and Cauligi S. Raghavendra, "Spray and Wait: An Efficient Routing Scheme for Intermittently Connected Mobile Networks", 2005.

[8] Sebastian Schildt and Lars Wolf, "RecentTrends: DTN Introduction \& Applications", 2011.

\section{Biodata Penulis}

Bima Adhiguna, lahir di Padang, 26 November 1994. Menamatkan jenjang S1 di Telkom University pada bulan Juli 2016. Bekerja sebagai Laboran di Fakultas Teknik Elektro Telkom University dan saat ini sedang melanjutkan jenjang S2 di Universitas Komputer Indonesia.

Tody Ariefianto Wibowo, menamatkan jenjang S1 di prodi Teknik Elektro STT Telkom tahun 2006 dan S2 di prodi Teknik Elektro ITB tahun 2010. Saat ini bekerja sebagai dosen di Fakultas Teknik Elektro, Universitas Telkom. Aktif pada kegiatan riset mengenai Delay Tolerant Network dan Network Virtualization.

Leanna Vidya Yovita, menamatkan jenjang S1 di prodi teknik elektro STT Telkom tahun 2006 dan S2 di prodi teknik elektro IT Telkom tahun 2011. Bekerja sebagai dosen di Fakultas Teknik Elektro Universitas Telkom. Fokus pada riset mengenai Ad hoc Network, terutama Delay Tolerant Network. 